\title{
The Effects of Manifold Flow on Mass Transport in Electrochemical Filter-Press Reactors
}

\author{
Á. Frías-Ferrer, J. González-García, and V. Sáez
}

New Developments in Electrochemistry, Sonoelectrochemistry and Bioelectrochemistry Group, Dept. of Chemical Physics, University Institute of Electrochemistry, University of Alicante, 03080 Alicante, Spain

\section{Ponce de León and F.C. Walsh}

Electrochemical Engineering Laboratory, Energy Technology Research Group, School of Engineering Sciences, University of Southampton, Southampton SO17 1BJ, U.K.

DOI 10.1002/aic.11426

Published online in Wiley InterScience (www.interscience.wiley.com).

The mass transport rates to planar electrodes, in a series of electrochemical laboratory filter-press reactors were measured to quantify the effects of the inlet and outlet design manifolds on the fluid flow. In small reactors, entrancelexit effects are especially important due to the localized generation of fluid recirculation zones, which affect the overall rate of mass transport. Limiting current data, the cathodic reduction of $\mathrm{Cu}(\mathrm{II})$ ions on a copper surface (under convective-diffusion control) were used to measure global mass transport coefficients. The data are compared with those from a well-characterized laboratory cell, the FM01-LC electrolyzer. The importance of manifold design in small-scale electrochemical reactors is discussed, and several dimensionless parameters are used to characterize the manifold geometry. (c) 2008 American Institute of Chemical Engineers AIChE J, 00: 000-000, 2008

Keywords: convective-diffusion, electrolyte manifolds, entrance effects, hydrodynamics, mass transport, turbulence

\section{Introduction}

The extrapolation of results from the laboratory to pilot and industrial scale requires careful consideration of the design and process conditions. Important factors include electrode and reactor geometry, fluid flow, electrode kinetics, electrolyte concentrations, current and electrical distributions, and heat transfer similarities. ${ }^{1,2}$ Mass transport and fluid dynamics are particularly important to the reaction environment during the scale-up process.

Correspondence concerning this article should be addressed to J. GonzálezGarcía at jose.gonzalez@ua.es.

(C) 2008 American Institute of Chemical Engineers
The common use of rectangular flow channels in electrochemical cells reflects the necessity to use a practical, modular design which facilitates production while realizing welldeveloped flow patterns. In most cells, a calming section inside the reactor is designed to restore the flow pattern disturbances of the electrolyte caused by the entrance manifolds. When no calming section is used within the reactor, the electrolyte contacts with the electrode immediately after entering the reactor and high values of the mass transport coefficient can be found; this is known as the entry effect. A similar situation occurs at the exit of the reactor if no calming section exists; the exit manifold disturbs the hydrodynamic regime causing high values of the mass transport coefficient. As the electrolyte reaches a fully developed flow along the electrode channel, the mass transport coefficient gradually decreases. 
Table 1. Selected Studies of Mass Transport in Electrochemical Filter-Press Cells

\begin{tabular}{|c|c|c|c|c|c|c|}
\hline \multicolumn{4}{|c|}{ Filter-Press Reactor } & \multicolumn{2}{|r|}{ Electrolyte } & \multirow[b]{2}{*}{$\begin{array}{l}\text { Authors, } \\
\text { Year, Ref }\end{array}$} \\
\hline $\begin{array}{l}\text { Channel } \\
\text { Breadth, } \\
B(\mathrm{~cm})\end{array}$ & $\begin{array}{l}\text { Channel } \\
\text { Length, } \\
L(\mathrm{~cm})\end{array}$ & $\begin{array}{l}\text { Channel } \\
\text { Thickness, } \\
S(\mathrm{~cm})\end{array}$ & $\begin{array}{l}\text { Electrode } \\
\text { Material }\end{array}$ & $\begin{array}{l}\text { Maximum } \\
\text { Fluid Velocity, } \\
\qquad v\left(\mathrm{~cm} \mathrm{~s}^{-1}\right)\end{array}$ & Composition & \\
\hline 3 & 4 & 0.6 & Titanium & 8.3 & $\begin{array}{r}5 \times 10^{-2} \mathrm{~mol} \mathrm{dm}^{-3} \mathrm{~K}_{3}\left[\mathrm{Fe}(\mathrm{CN})_{6}\right]+5 \times 10^{-2} \\
\mathrm{~mol} \mathrm{dm}^{-3} \mathrm{~K}_{4}\left[\mathrm{Fe}(\mathrm{CN})_{6}\right] \text { in } 1 \mathrm{~mol} \mathrm{dm}^{-3} \mathrm{KOH}\end{array}$ & $\begin{array}{l}\text { Barral et al., } \\
1991^{9}\end{array}$ \\
\hline 4 & 16 & 0.55 & $\begin{array}{r}\text { Nickel or } \\
\text { copper }\end{array}$ & 10.0 & $\begin{array}{l}\text { For nickel electrodes: } 2 \times 10^{-3} \mathrm{~mol} \mathrm{dm}^{-3} \\
\mathrm{~K}_{3}\left[\mathrm{Fe}(\mathrm{CN})_{6}\right]+5 \times 10^{-3} \mathrm{~mol} \mathrm{dm}^{-3} \\
\mathrm{~K}_{4}\left[\mathrm{Fe}(\mathrm{CN})_{6}\right] \text { in } 1 \mathrm{~mol} \mathrm{dm}^{-3} \mathrm{KOH} \text {. For copper } \\
\text { electrodes: } 7 \times 10^{-3} \mathrm{~mol} \mathrm{dm}^{-3} \mathrm{CuSO}_{4} \text { in } 1.5 \\
\text { mol dm }\end{array}$ & $\begin{array}{l}\text { Brown et al., } \\
1993^{10}\end{array}$ \\
\hline 10 & 10 & $\begin{array}{l}S_{\text {cathode }}: 2 \mathrm{~cm} \\
\quad S_{\text {anode }}: 1.2 \mathrm{~cm}\end{array}$ & $\begin{array}{l}\text { Platinized } \\
\text { titanium }\end{array}$ & 20.6 & $\begin{array}{l}\text { Catholyte: } 2 \times 10^{-3} \mathrm{~mol} \mathrm{dm}^{-3} \mathrm{~K}_{3}\left[\mathrm{Fe}(\mathrm{CN})_{6}\right]+ \\
5 \times 10^{-3} \mathrm{~mol} \mathrm{dm}{ }^{-3} \mathrm{~K}_{4}\left[\mathrm{Fe}(\mathrm{CN})_{6}\right] \text { in } 1 \mathrm{~mol} \\
\mathrm{dm}^{-3} \mathrm{KOH} \text {. Anolyte: } 1 \mathrm{~mol} \mathrm{dm}^{-3} \mathrm{KOH}\end{array}$ & $\begin{array}{l}\text { Ralph et al., } \\
1996^{11}\end{array}$ \\
\hline 4 & 16 & 0.55 & Copper & 11.2 & $\begin{array}{l}5 \times 10^{-3} \mathrm{~mol} \mathrm{dm}^{-3} \mathrm{CuSO}_{4} \text { in } 1.5 \mathrm{~mol} \mathrm{dm}^{-3} \\
\mathrm{H}_{2} \mathrm{SO}_{4}\end{array}$ & $\begin{array}{l}\text { Brown et al., } \\
1992^{12}\end{array}$ \\
\hline
\end{tabular}

In small electrochemical cells, typically used in the laboratory, calming zones are usual for electroanalytical, reaction mechanism studies together with spectroelectrochemistry. ${ }^{3}$ The small cells are attractive during process development, because of the low requirements of volume and power. When short or zero calming sections are incorporated, the cost of the electrochemical cells is low which is useful if a high-electrode area/volume ratio is required, as in the case of three-dimensional electrodes. ${ }^{4-6}$ In large cells, where calming zones can sometimes be justified, the effect on the hydrody- namics and global mass transport rates because of the entrance and exit manifolds can be minimized.

\section{The literature on entrance and exit effects}

Entrance/exit effects on mass transport rates and flow pattern distribution are commonly studied by limiting current measurements under convective-diffusion mass transport control. ${ }^{7,8}$ Table 1 shows several examples of cells with different electrode channel dimensions, which include various

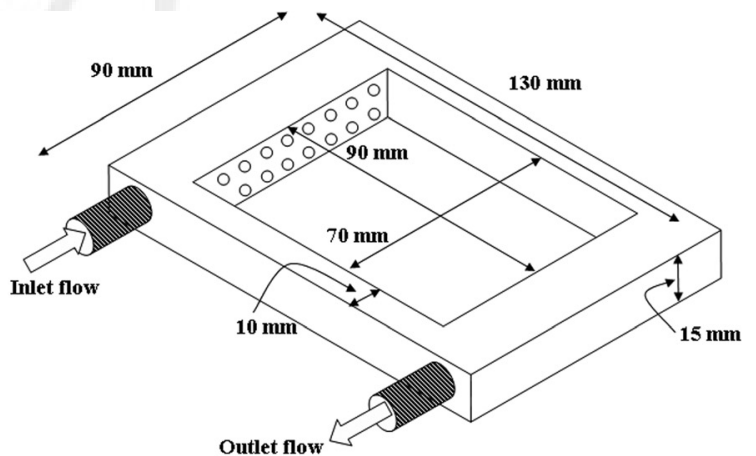

(b)

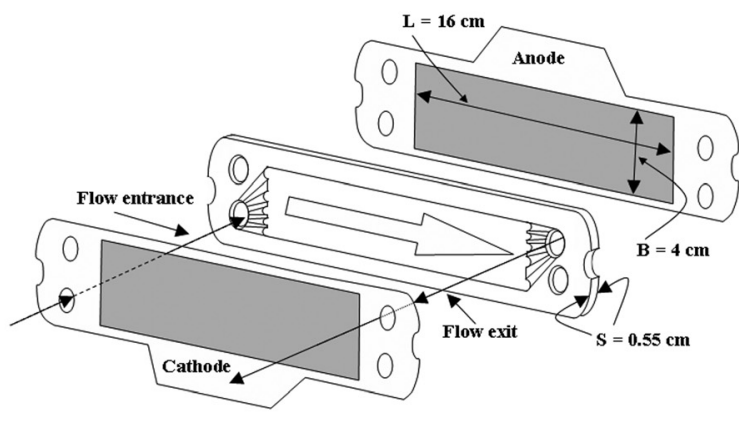

(d)

(c)

Figure 1. Filter-press cell frames: University of Alicante (UA).

(a) UA16.15 $(B=4.0 \mathrm{~cm}, S=1.5 \mathrm{~cm}, L=4.0 \mathrm{~cm})$, (b) UA63.15 $(B=7.0 \mathrm{~cm}, S=1.5 \mathrm{~cm}, L=9.0 \mathrm{~cm}),(\mathrm{c}) \mathrm{UA} 63.03(B=7.0 \mathrm{~cm}$, $S=0.3 \mathrm{~cm}, L=9.0 \mathrm{~cm})$, and (d) FM01-LC electrolyzer in undivided configuration $(B=4.0 \mathrm{~cm}, S=0.55 \mathrm{~cm}, L=16.0 \mathrm{~cm})$. The thickness of the electrolyte channel includes the gaskets, which are not shown in the figure. 


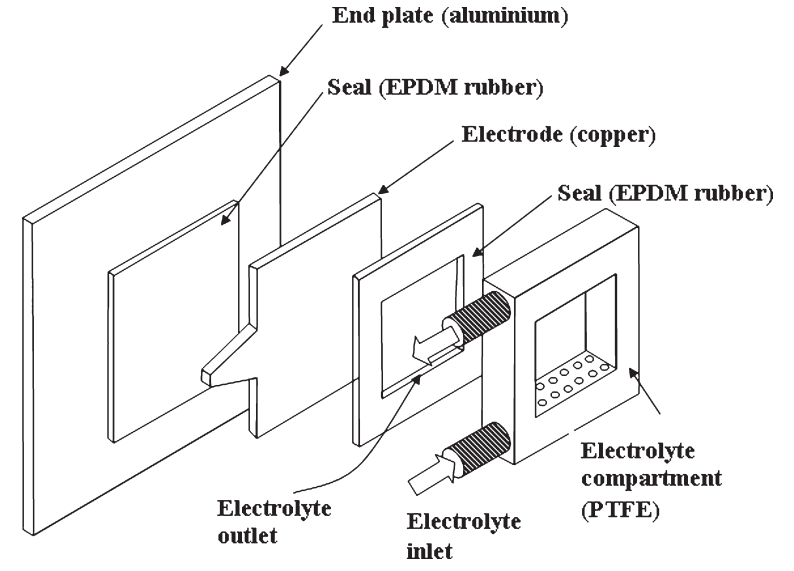

Figure 2. Construction of one-half of the UA electrochemical reactor; the turbulence promoter was contained within the electrolyte compartment channel.

entrance/exit manifolds designs. ${ }^{9-12}$ For example, Wragg et al. $^{13}$ investigated the interaction of electrolyte jets when nozzles where installed in a multi-entry port manifold. Using microelectrodes, they obtained the distribution of mass transport coefficients in two electrochemical cells with circular and square cross-sections area, respectively. They suggested that the change in the shape of the flow section would result in a greater separation length between the electrolyte jets than in pipe expansions, as shown by Tagg et al. ${ }^{7}$ in a previous work. Chouikhi et al. ${ }^{14}$ confirmed these results.

Goodridge et al. ${ }^{15}$ compared two reactors having electrode areas of 225 and $2025 \mathrm{~cm}^{2}$, which contained a series of $3 \mathrm{~mm} \times$ $5 \mathrm{~mm}$ holes in the inlet and exit manifolds. Examination of the mass transport coefficients showed that significant entrance/exit effects were observed in cells with $<2000 \mathrm{~cm}^{2}$ area, and concluded that such small reactors should not be used for scale-up. Wragg et al. ${ }^{16,17}$ extended this work using minielectrodes to map the two-dimensional mass transport coefficient distribution in a small cell in the absence and presence of baffles. The cell without baffles had a dead zone in the center, while the cell with baffles showed larger mass transport coefficients. Oduoza and Wragg ${ }^{18,19}$ analyzed the influence of manifold design in these reactors, while Szánto et al. ${ }^{20}$ reported a two-dimensional mass transport profile map of the FM01 filter-press cell using an array of minielectrodes.

Djati et al. ${ }^{21}$ proposed a number of dimensionless expansion factors following the analysis of the mass transport characteristics of different inlet types in a rectangular reactor (slits or tubes). These factors result in relationships between the cross-sectional area of the fluid inlet and the electrochemical reactor channel, which result in a unique correlation between mass transport and fluid flow conditions. Wang et al. $^{22}$ used numerical simulations to investigate the inlet/ exit effects, and the errors in the mass transport determination when small insulated electrodes were used.

\section{Flow regime}

In a circular pipe of diameter $d$, turbulent flow generally occurs at $R e_{d}>2300$, whereas in a rectangular duct it will be observed at $R e_{d e}>3000$, where $d_{e}$ is the equivalent diameter, $d_{e}=2(B S) /(B+S)$, where $B$ and $S$ are the width and the thickness of the electrolyte channel, respectively. ${ }^{23}$ At smooth flat plate, the boundary layer is initially laminar, passes through a transition phase, and becomes turbulent at a Re value between $1 \times 10^{5}$ and $3 \times 10^{6} .^{23}$ Because of the sensitivity of the flow pattern to initial conditions and external disturbances, the precise Reynolds number at which the flow conditions become turbulent can only be predicted under well-controlled laboratory conditions. A minimum downstream length is required for a fully developed laminar flow to exist, because of the disturbances at the inlet of the electrolyte. This length is called entrance length, $L^{*}$, which for a circular pipe of diameter $d$, is as follows ${ }^{24}$ :

$$
\begin{gathered}
\text { Laminar flow: } L^{*} / d=0.06 R e \\
\text { Turbulent flow: } L^{*} / d=4.4 R e^{1 / 6}
\end{gathered}
$$

The downstream distance from the reactor entrance before turbulent flow is fully developed, in general, at a point approximately $x / d=20-40$ for pipe flow or $x / d_{e}=20-100$ for channel flow. ${ }^{23,24}$

Mean velocity profiles can become fully developed at sufficient distances along an electrode. However, the distance required to achieve fully developed profiles for the turbulent

\begin{tabular}{|c|c|c|c|c|c|c|c|}
\hline Reactor & $\begin{array}{l}\text { Channel } \\
\text { Breadth, } \\
B(\mathrm{~cm})\end{array}$ & $\begin{array}{l}\text { Channel } \\
\text { Length, } \\
L(\mathrm{~cm})\end{array}$ & $\begin{array}{l}\text { Channel } \\
\text { Thickness, } \\
S(\mathrm{~cm})\end{array}$ & $\begin{array}{c}\text { Projected } \\
\text { Electrode } \\
\text { Area, } A\left(\mathrm{~cm}^{2}\right)\end{array}$ & Inlet/Exit Ports & $\begin{array}{c}\text { Equivalent } \\
\text { Diameter, } d_{e}=2 B S / \\
(B+S)(\mathrm{cm})\end{array}$ & $\begin{array}{c}\text { Area Ratio } \\
\text { Manifold Design } \\
\text { Parameter, } \zeta=\frac{\left(n \cdot \pi \cdot \frac{d^{2}}{4}\right)}{\mathrm{BS}}\end{array}$ \\
\hline UA16.15 & 4.0 & 4.0 & 1.50 & 16 & $\begin{array}{l}2 \text { parallel rows, each of } 7 \\
\text { circular holes (diameter }= \\
2 \mathrm{~mm} \text { ) }\end{array}$ & 2.18 & 0.073 \\
\hline UA63.15 & 7.0 & 9.0 & 1.50 & 63 & $\begin{array}{l}2 \text { parallel rows, each of } 13 \\
\text { circular holes (diameter }= \\
2 \mathrm{~mm})\end{array}$ & 2.47 & 0.078 \\
\hline UA63.03 & 7.0 & 9.0 & 0.30 & 63 & $\begin{array}{l}2 \text { ports in one row }(12 \mathrm{~mm} \\
\text { aperture ports) }\end{array}$ & 0.58 & 0.343 \\
\hline FM01-LC & 4.0 & 16.0 & 0.55 & 64 & $\begin{array}{l}4 \text { rectangular jet way flow } \\
\text { distributors, each of } 0.057 \\
\mathrm{~cm}^{2} \text { cross-sectional area }\end{array}$ & 0.97 & 0.105 \\
\hline
\end{tabular}

Table 2. Characteristic Dimensions of Selected Laboratory Filter-Press Reactors, $n=n_{r} \cdot n_{h}$

UA.XX.YY: University of Alicante reactors, where XX is the active electrode area in $\mathrm{cm}^{2}$, and $\mathrm{YY}$ is the breath of the electrolyte compartment in mm. FM01LC: commercial reactor from INEOS Chlor Chemicals Ltd. 


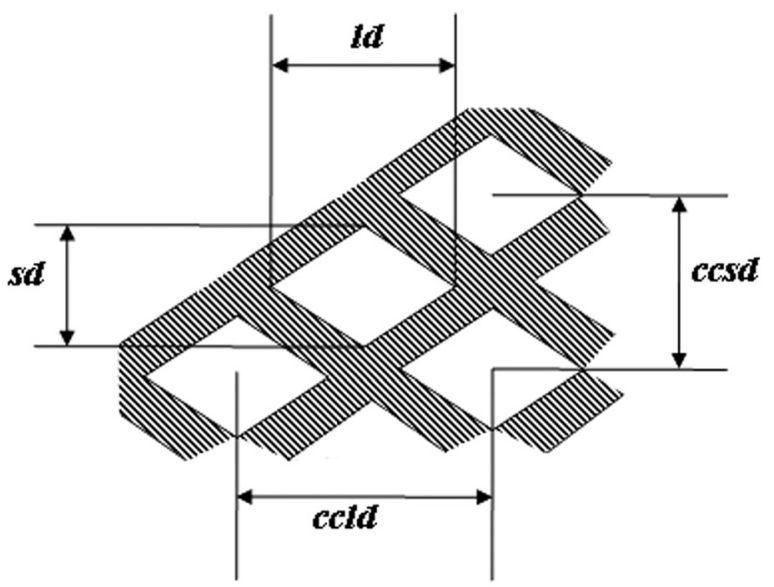

(a)
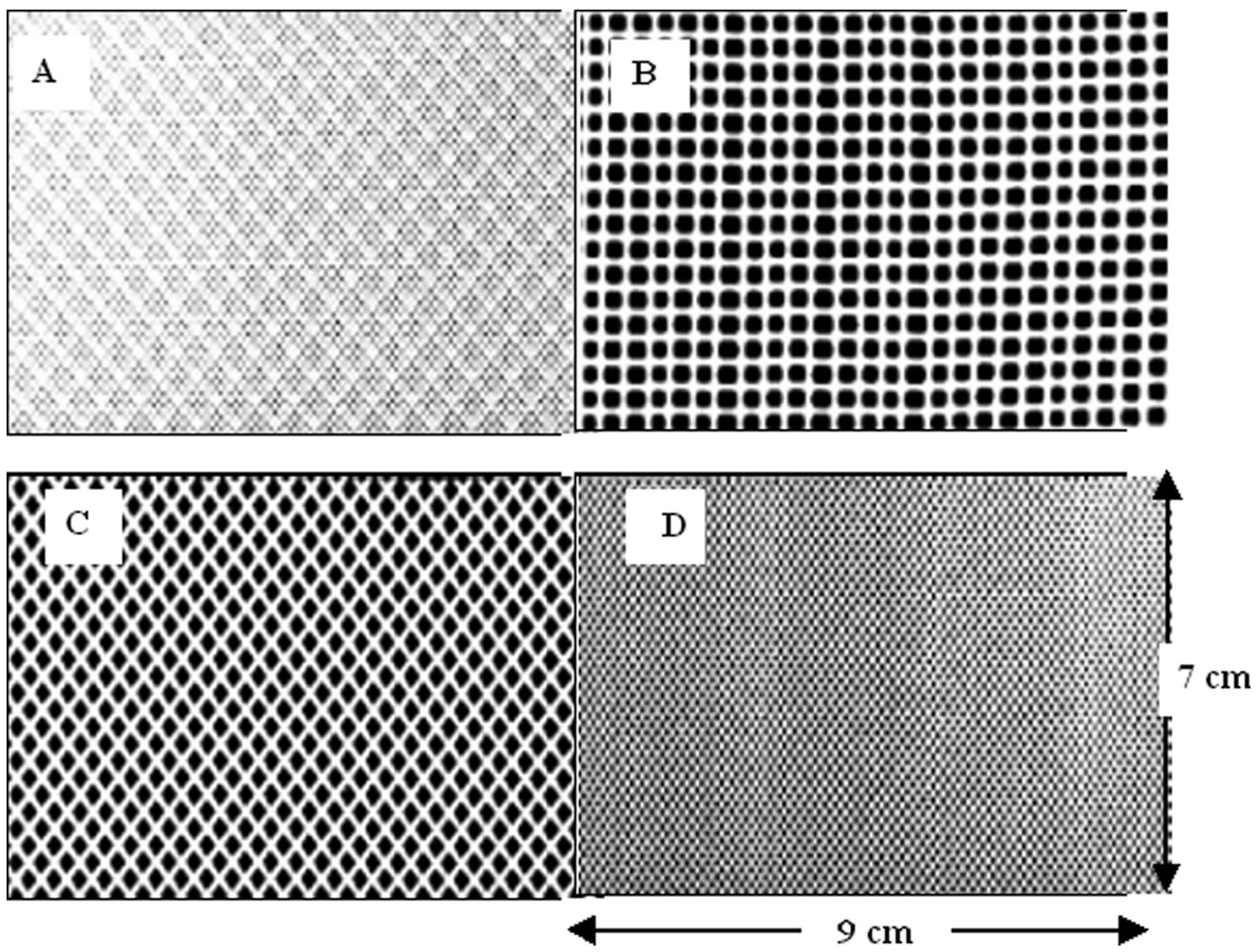

(b)

Figure 3. Turbulence promoters.

(a) Definition sketch showing the important dimensions and (b) optical photographs.

fluctuating velocity can be several times longer than predicted values. ${ }^{23}$ A more specific approach was taken by Pickett and Wilson, ${ }^{8}$ who found that fully developed flow within a parallel plate reactor occurred after a distance of approximately $L^{*}=6 \cdot d_{e}$.
The aim of this article is to compare the mass transport, flow characteristics including the effect of turbulence promoters on mass transport within the rectangular channel of practical filter-press reactors. This comparison is based on the manifolds geometry of two reactors constructed at the 
Table 3. Characteristics of Plastic Mesh Turbulence Promoters Used in this Study

\begin{tabular}{|c|c|c|c|c|}
\hline Parameters & Promoter A & Promoter $\mathrm{B}^{*}$ & Promoter C & Promoter D \\
\hline $\mathrm{sd}(\mathrm{mm})$ & 1.5 & 5.0 & 5.0 & 7.0 \\
\hline ld $(\mathrm{mm})$ & 2.0 & 5.0 & 6.0 & 9.0 \\
\hline $\operatorname{ccld}(\mathrm{mm})$ & 3.1 & 5.0 & 8.7 & 12.5 \\
\hline $\operatorname{ccsd}(\mathrm{mm})$ & 2.3 & 5.0 & 6.6 & 13.2 \\
\hline Promoter thickness (mm) & 1.0 & 1.0 & 2.0 & 2.9 \\
\hline FT $(\mathrm{mm})$ & 0.5 & $1.0-1.5$ & 1.2 & 5.5 \\
\hline Porosity of promoter & 0.69 & 0.70 & 0.73 & 0.80 \\
\hline $2 \mathrm{D}$ projected open space & 0.47 & 0.54 & 0.57 & 0.58 \\
\hline Fraction of surface directly blocked by fibers & 0.36 & 0.46 & 0.28 & 0.29 \\
\hline
\end{tabular}

sd is the short diagonal; ld is the long diagonal; ccld is the distance between the center of a promoter gap and the center of the next closest gap in the ld direction; ccsd is the distance between the center of a promoter gap and the center of the next closest gap in the sd direction; and FT is the thickness of the fiber.

*Dimensions for a rectangular gap in promoter B. Sufficient number of promoters were used to completely fill the rectangular flow channel.

University of Alicante (UA): UA16.15 and UA63.15, with the UA63.03 ${ }^{25}$ and the FM01-LC ${ }^{10,26}$ filter-press reactors. A novel aspect in this study is the use of dimensionless groups to characterize the effect of the inlet and outlet manifold design on the mass transport rates.

\section{Experimental Details}

The filter-press cells, UA16.15, UA63.15, and UA63.03 are shown in Figures 1a-c, and Figure 1d shows the FM01LC reactor, the later being used for comparison purposes.

F2 Figure 2 shows an exploded view of the UA16.15 cell, and the characteristic dimensions of these cells are shown in Table 2. The UA cells were constructed using polytetrafluoroethylene (PTFE), and the flat gasket seals were made of ethylene-polypropylene-diene (EPDM). Aluminium endplates and steel tie-bolts were used to compress the reactor frames. ${ }^{11}$ A stack of polyvinylchloride (PVC) turbulence promoters, shown schematically in Figure 3, was used to fill the ties of these promoters.

The working and counter electrodes were $2.5-\mathrm{mm}$ thick copper plates polished to a mirror finish using successively finer grades of alumina powder $(1.0,0.3$, and $0.05 \mu \mathrm{m})$. A saturated calomel reference electrode connected via a plastic tube, Luggin capillary (ca. $1 \mathrm{~mm}$ inside diameter) was used to monitor the working electrode potential. The change in the limiting current with volumetric flow rate of the cathodic reduction of copper was used to measure the global mass transport coefficients. ${ }^{7}$ The electrolyte consisted of $\mathrm{Cu}$ (II) (as $\mathrm{CuSO}_{4}$ ) between $1 \times 10^{-3}$ and $4 \times 10^{-3} \mathrm{~mol} \mathrm{dm}^{-3}$ concentration dissolved in $0.5 \mathrm{~mol} \mathrm{dm}{ }^{-3} \mathrm{Na}_{2} \mathrm{SO}_{4}$ at $\mathrm{pH}$ 2. Experiments were carried out in the arrangement as shown in Figure 4 at temperature of $293 \pm 1 \mathrm{~K}$. Current vs. potential curves were obtained with a Philips PM 8133 X-Y chart recorder using an AMEL model 553 potentiostat and EG\&G PARC model 175 waveform generator.

\section{Results and Discussion}

\section{Pressure drop measurements}

Figure 5 shows the friction factor, $f$ vs. Re number, for the UA16.15 and UA63.15 reactors, compared with the UA63.03 and the FM01-LC reactor. The curves for the UA cells were obtained in an empty channel while the two curves for the FM01-LC are with the turbulence promoter D and in an empty channel. The friction factor can be calculated from the pressure drop using the formula: $f=\Delta P d_{\mathrm{e}} / 2 \rho L v^{2}$. The experimental values of the friction factor for the four reactors are larger than the theoretical values, which predicted values of $24 / R e$ in an open channel in fully developed laminar flow at $R e<2300 .^{24}$ The variation of the friction factor with $R e$ for the three UA reactors is similar and becomes approximately constant at $R e>1000$. Similar results have been found in the literature for open-inlet slotted manifolds in $100 \mathrm{~cm} \times$ $9 \mathrm{~cm} \times 0.2 \mathrm{~cm}$ compartments by Hine et al., ${ }^{27}$ but at considerably lower Reynolds numbers. The friction factor with the turbulence promoter D in the FM01-LC reactor ${ }^{28}$ shows similar values as the UA 63.03 reactor, whereas the friction factor in an empty channel is closer to the theoretical prediction. The critical Reynolds number $R e_{\text {crit }}$, found in literature for a flat plate in a similar geometry varies within a certain range

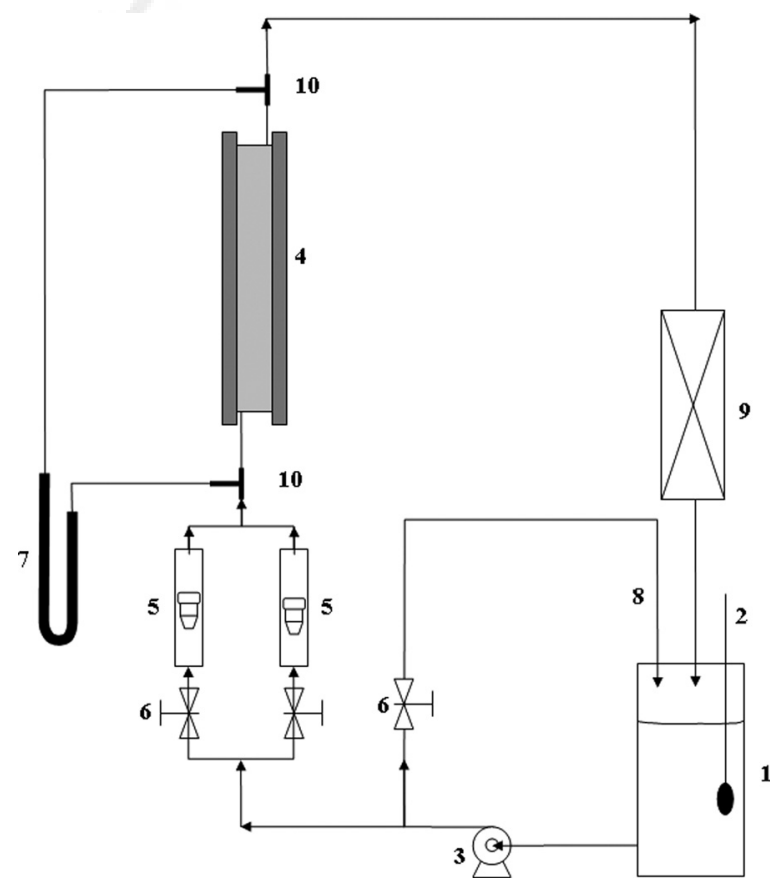

Figure 4. The electrolyte flow arrangement.

(1) Reservoir, (2) thermometer, (3) centrifugal pump, (4) electrochemical reactor, (5) flow meters, (6) flow control valves, (7) U-tube water manometer, (8) by-pass flow, (9) heat exchanger, and (10) pressure taps. 


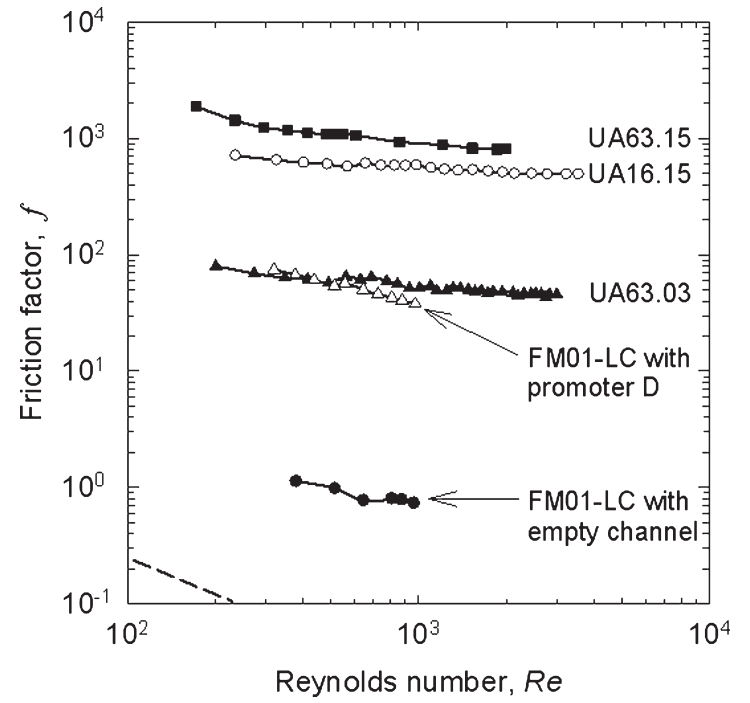

Figure 5. Log-log plot of the friction factor vs. Reynolds number.

UA reactors with no turbulence promoter: $(\bigcirc)$ UA16.15,

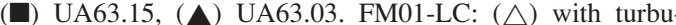
lence promoter $\mathrm{D}$ and $(\mathbf{)})$ empty channel. The dashed line (- -) indicates the theoretical friction factor in a rectangular channel of a laminar flow. ${ }^{24}$

of values; Levich ${ }^{29}$ proposed $R e_{\text {crit }}=1500$ for a flat plate, but the value decreased substantially when turbulence promoters or baffles were used in the flow channel. Coeuret and Storck ${ }^{30}$ proposed a range between $3 \times 10^{5}$ and $3 \times 10^{6}$ for the same geometry, which is similar to other values previously reported. ${ }^{23}$ In the case of the UA reactors, the $R e_{\text {crit }}>$ 1000 value is less compared with the literature. This is due to the large inlet/exit effects in the UA reactors caused by the inlet and exit ports, which result in flow disturbances. It is clear that a strong power consumption penalty for the UA16.15 and UA63.15 reactors has to be paid due to the small bore holes in the multiple entry ports design in comparison with the UA63.03 cell, which contain two thin opened slots in the entrance manifolds. Table 4 shows the entrance length $L^{*}$, for the UA reactors according to Eqs. 1 and 2. The UA16.15 and UA63.15 reactors have larger theoretical entrance lengths than their downstream dimensions, and only the UA63.03 and FM01-LC reactors would show some partially fully developed fluid flow using this approximation. This is in agreement with the fact that although the friction factor values are high, the values obtained for the UA63.03 reactor are closer to the theoretical values than the UA16.15 and UA63.15 reactors. These results highlight the importance of the inlet port design and underline the need to characterize the manifold geometry.

\section{Mass transport studies in the absence and presence of turbulence promoters}

Full Electrode Area. To obtain information about the behavior of the UA laboratory filter-press reactors with different inlet ports designs, mass transport studies were focused on the determination of the global mass transport coefficient. These were obtained from the global (space-averaged) limiting current for the reduction of $\mathrm{Cu}(\mathrm{II})$ ions in aqueous sulfate solution according to the reaction as follows:

$$
\mathrm{Cu}(\mathrm{II})+2 \mathrm{e}^{-} \rightarrow \mathrm{Cu}(0)
$$

Figure 6a shows a typical current density vs. potential curve for the deposition of copper from $2.7 \times 10^{-3} \mathrm{~mol} \mathrm{dm}^{-3}$ $\mathrm{Cu}$ (II) ion in the UA16.15 reactor. Similar voltammograms were obtained with the UA63.15 reactor. From the limiting current plateau, the potential range at which the process is under full mass transport control can be determined. Figure $6 \mathrm{~b}$ shows the current density vs. time curve obtained from potential steps experiments at $-500 \mathrm{mV}$ vs. SCE (corresponding to complete mass transport control) starting at the rest potential for the UA16.15 reactor. The experiments were carried out at a mean linear flow velocity in the range of $0.7-8.5 \mathrm{~cm} \mathrm{~s}^{-1}$ and with $\mathrm{Cu}(\mathrm{II})$ ion concentrations in the range of $1 \times 10^{-3}$ to $4.1 \times 10^{-3} \mathrm{~mol} \mathrm{dm}^{-3}$. The global mass transport coefficient was obtained from the slope of the curve $j_{L}$ vs. $c_{\mathrm{b}}$ for each volumetric flow rate using the equation:

$$
k_{\mathrm{m}}=\frac{j_{L}}{z F c_{\mathrm{b}}}
$$

where $A$ is the electrode area, $z$ is the number of electrons, $F$ is the Faraday constant, and $c_{\mathrm{b}}$ is the bulk concentration of $\mathrm{Cu}$ (II) ions. The mass transfer coefficients at a controlled mean electrolyte flow velocity were fitted using the dimensionless correlation as follows:

$$
S h=a \cdot R e^{b} \cdot S c^{c}
$$

where $S h$ is the Sherwood number $\left(=k_{m} d_{e} / D\right), R e$ is the Reynolds number $\left(=v d_{e} / v\right)$, and $S c$ is the Schmidt number $(=v / D) ; a, b$, and $c$ are empirical numbers found from a statistical correlation of the experimental data. Table 5 shows the effect of operational variables, as in Eq. 5, on mass trans-

\begin{tabular}{|c|c|c|c|c|c|c|c|c|c|}
\hline Reactor & $\begin{array}{c}d_{e}=2 B S / \\
(B+S)(\mathrm{cm})\end{array}$ & $L(\mathrm{~cm})$ & $\begin{array}{c}L^{*}= \\
6 d_{e}(\mathrm{~cm})\end{array}$ & $\begin{array}{c}L^{*}= \\
20 d_{e}(\mathrm{~cm})\end{array}$ & $\begin{array}{c}L^{*}= \\
100 d_{e}(\mathrm{~cm})\end{array}$ & \multicolumn{2}{|c|}{$\begin{array}{l}L^{*}(\text { laminar })= \\
0.06 \operatorname{Re} d_{e}(\mathrm{~cm})\end{array}$} & \multicolumn{2}{|c|}{$\begin{array}{l}L^{*}(\text { turbulent })= \\
4.4 R e^{1 / 6} d_{e}(\mathrm{~cm})\end{array}$} \\
\hline UA16.15 & 2.18 & 4 & 13.08 & 43.6 & 218 & $\begin{array}{l}R e=272 \\
R e=2,571\end{array}$ & $\begin{array}{l}35.6 \\
336\end{array}$ & $\begin{array}{l}R e=272 \\
R e=2,571\end{array}$ & $\begin{array}{l}24.4 \\
35.0\end{array}$ \\
\hline UA63.15 & 2.47 & 9 & 14.82 & 49.5 & 247 & $R e=170$ & 25.0 & $R e=170$ & 25.5 \\
\hline UA63.03 & 0.58 & 9 & 3.48 & 11.6 & 58 & $\begin{array}{l}\mathrm{Re}=1,964 \\
R e=171 \\
\operatorname{Re}=629\end{array}$ & $\begin{array}{c}291 \\
4.07 \\
21.9\end{array}$ & $\begin{array}{l}R e=1,964 \\
R e=171 \\
R e=629\end{array}$ & $\begin{array}{c}38.4 \\
5.60 \\
7.50\end{array}$ \\
\hline FM01-LC & 0.97 & 16 & 5.82 & 19.4 & 97 & $\begin{array}{l}\operatorname{Re}=200 \\
\operatorname{Re}=1,000\end{array}$ & $\begin{array}{l}11.6 \\
58.2\end{array}$ & $\begin{array}{l}R e=200 \\
R e=1,000\end{array}$ & $\begin{array}{l}10.3 \\
13.5\end{array}$ \\
\hline
\end{tabular}

Table 4. Length Distance Values According to Literature Expressions for UA and FM01-LC Filter-Press Reactors 


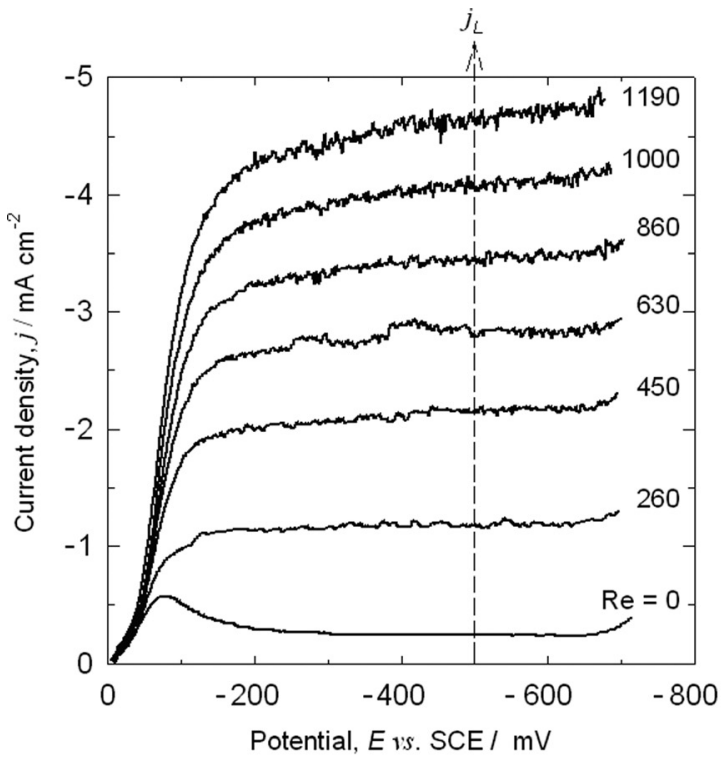

(a)

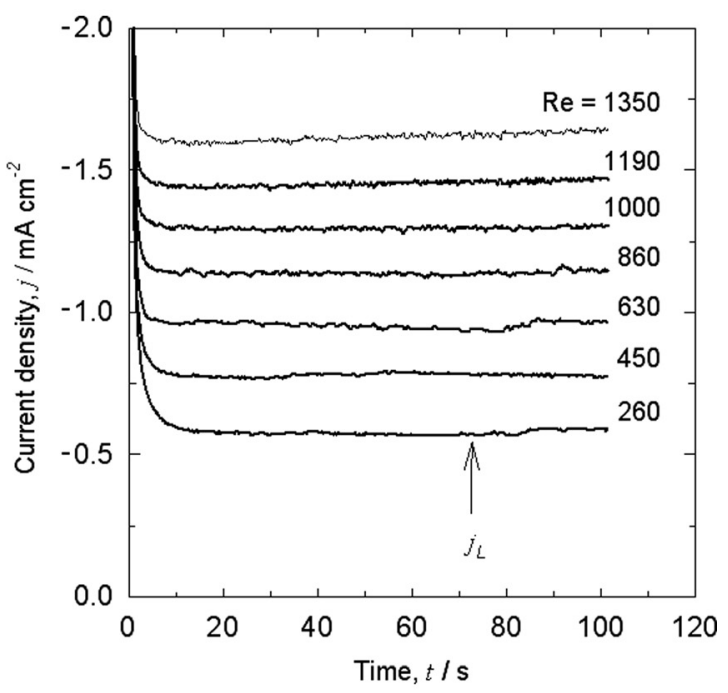

(b)

Figure 6. Mass transport measurements for the reduction of $2.7 \times 10^{-3} \mathrm{~mol} \mathrm{dm}^{-3} \mathrm{Cu}(\mathrm{II})$ ion in $0.5 \mathrm{~mol} \mathrm{dm}^{-3}$ sodium sulfate at $\mathrm{pH} 2$ and at controlled flow rates.

(a) Steady-state current density vs. electrode potential (at $2 \mathrm{mV} \mathrm{s}^{-1}$ ) curves used to determine potential window of mass transport control. (b) Current density vs. time curves to measure the value of the limiting current. The potential was stepped from the open-circuit value to $-0.5 \mathrm{~V}$ vs. SCE. The working and counter electrodes in the UA16.15 reactor were 2.5 -mm thick, copper plates.

port in the UA reactors and in the FM01-LC for comparison. The values of the coefficients " $a$ " and " $b$ " clearly show the influence of the manifold design and the presence or absence of turbulence promoters. Values of " $a$ " for the UA16.15 and UA63.15 reactors with no turbulence promoter are higher (close to one) than the UA63.03 and FM01-LC reactors. In contrast, " $b$ " is lower for the UA16.15 and UA63.15 reactors when compared with the values for the UA63.03 and FM01LC cells. Assuming that " $a$ " is characteristic of the design geometry and " $b$ " reflects the fluid flow influence, it is clear that a lower value of " $b$ " indicates a major relevance of manifold design in the mass transport conditions. This is in agreement with the larger theoretical entrance lengths determined for the UA16.15 and UA63.15 reactors in comparison with the length for the UA63.03 and FM01-LC reactors calculated in Table 4. The implementation of the turbulence promoters provides not only an increased value of the coefficient " $a$ " but also a decreased coefficient " $b$ ", which reflects a decrease of the fluid flow influence in the mass transport and a major relevance of inlet/outlet configuration. In the presence of the turbulence promoters in the UA reactors with large theoretical entrance lengths, the value of " $a$ " does not increase substantially; using promoter A, the increase is $3 \%$ for the UA 16.15 and $54 \%$ for UA 63.15, while with promoter C " $a$ " increases $16 \%$ for the reactor UA 63.15. In contrast, using promoters $\mathrm{A}$ and $\mathrm{C}$, the coefficient " $a$ " increased 220 and $150 \%$, respectively, for reactor UA63.03, and $235 \%$ for the FM01-LC reactor when turbulence promoter D was used. Similar results have been found in literature. $^{11}$

Partially Blocked Electrodes Study: Entrance and Exit Effects. The effects caused by the entrance and exit manifolds can be followed by changes of the global mass transport coefficient obtained from measurements of the limiting current, $I_{\mathrm{L}}$, using Eq. 4. The methods for the determination of this effect include the use of minielectrodes, ${ }^{13}$ segmented electrodes, ${ }^{15}$ or partially blocked electrodes. ${ }^{10,31}$ In the experiments of this section, the working electrode of the

Table 5. Dimensionless group mass transport correlations $\left(S h=a \cdot R e^{b} \cdot S c^{0.33}\right)$ for selected laboratory filter-press reactors

\begin{tabular}{|c|c|c|c|c|}
\hline Reactor & Channel Conditions & $A$ & $b$ & $R e$ and $S c$ Conditions \\
\hline \multirow[t]{3}{*}{ UA16.15 } & Empty channel & 1.08 & 0.61 & $S c=1,559 ; 272<\operatorname{Re}<2,571$ \\
\hline & Promoter A & 1.11 & 0.53 & $272<\operatorname{Re}<2,571$ \\
\hline & Promoter C & 1.25 & 0.56 & $272<\operatorname{Re}<2,571$ \\
\hline \multirow[t]{2}{*}{ UA63.15 } & Empty channel & 0.84 & 0.63 & $S c=1,559 ; 170<R e<1,664$ \\
\hline & Promoter A & 1.29 & 0.44 & $170<\operatorname{Re}<1,964$ \\
\hline \multirow[t]{3}{*}{ UA63.03 } & Empty channel & 0.17 & 0.82 & $S c=1,559 ; 117<\operatorname{Re}<629$ \\
\hline & Promoter A & 0.54 & 0.59 & $117<\operatorname{Re}<629$ \\
\hline & Promoter C & 0.43 & 0.63 & $117<\operatorname{Re}<629$ \\
\hline \multirow[t]{2}{*}{ FM01-LC } & Empty channel & 0.22 & 0.71 & $S c=1562 ; 200<R e<1,000$ \\
\hline & Promoter D & 0.74 & 0.62 & $200<\operatorname{Re}<1,000$ \\
\hline
\end{tabular}


UA16.15 reactor was masked from the electrolyte with plastic tape to evaluate the effects of the entrance and exit manifolds. The blocked area of electrodes served as calming zones. The mass transport coefficients were calculated and fitted into the dimensionless correlation, Eq. 5.

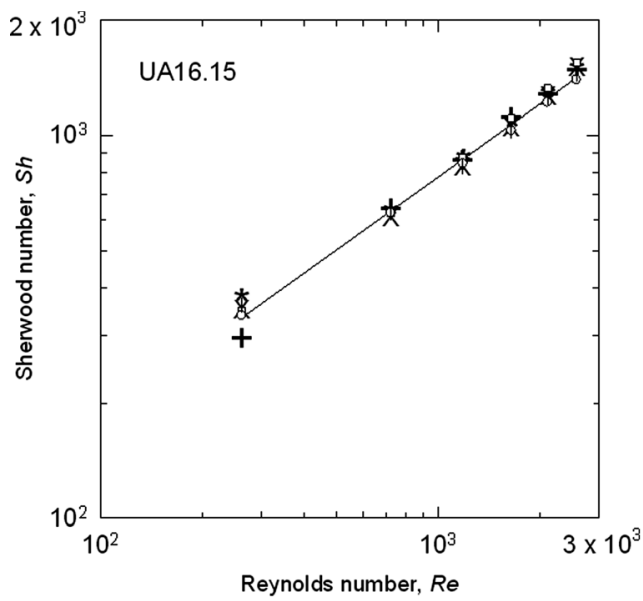

(a)

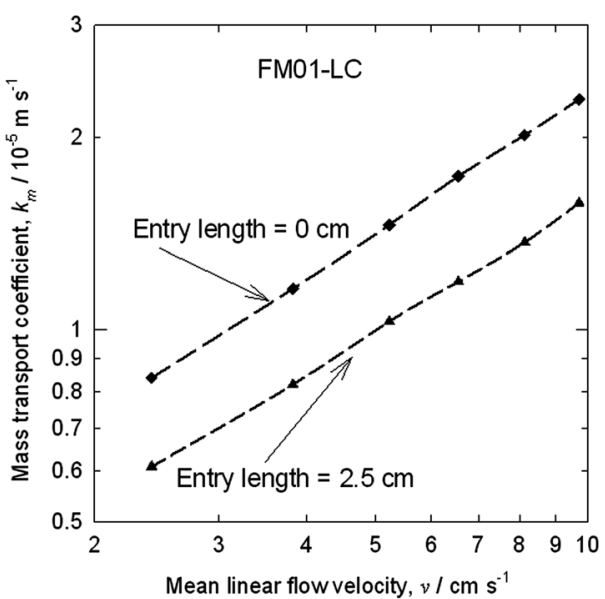

(b)

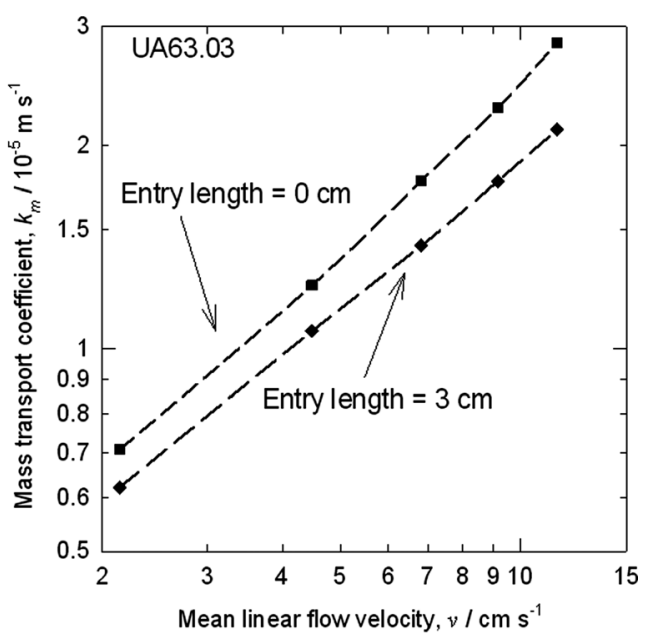

(c)
The dimensionless correlation plotted in Figure 7a corresponds to different exposed areas of the electrode, between 3 and $16 \mathrm{~cm}^{2}$. The mass transport data for all the areas fit well into a single line with the dimensionless correlation: $S h=$ $0.54 R e^{0.63} \mathrm{Sc}^{0.33}$. The study shows that when the area of the electrode is small and in a highly turbulent flow regime, the entire compartment operates under the entrance and exit effects with little influence of the fluid flow. For comparison purposes, the results of the mass transport coefficient with the mean linear flow velocity obtained for the FM01-LC reactor, Figure $7 \mathrm{~b},{ }^{10}$ and UA63.03, ${ }^{25}$ Figure $7 \mathrm{c}$, are also shown. The plots show that the mass transport coefficient decreased as the length of the covered area segments of the electrode was increased. The entrance/exit effects in the FM01-LC filter-press type reactor make a significant contribution to the value of the global mass transport coefficient, $k_{\mathrm{m}}$, when the entrance length to the active electrode section increased, the length of the recirculation zone is reduced, and $k_{m}$ showed lower values.

\section{Effect of turbulence promoters on the mass transport conditions in small reactors}

The effect of turbulence promoters can be easily observed using the enhancement factor $\gamma$, defined by Brown et al. ${ }^{28}$ as the ratio between the mass transport in an empty channel and a channel filled with a turbulence promoter ${ }^{32,33}$ as follows:

$$
\begin{aligned}
& \gamma_{\mathrm{mt}}=k_{\mathrm{m} \text { (with turbulence promoter })} / k_{\mathrm{m}(\text { empty channel })} \\
& \gamma_{\mathrm{mt}}=S h_{(\text {with turbulence promoter })} / S h_{(\text {empty channel })}
\end{aligned}
$$

Figures $8 \mathrm{a}$ and $9 \mathrm{a}$ show the $S h$ vs. $R e$ correlation for the UA16.15 and UA63.15 reactors, respectively, operating with and without turbulence promoters. The curves show that the Sh number calculated when the electrolyte channel was empty was higher than when the channel was filled with turbulence promoters. Figures $8 \mathrm{~b}$ and $9 \mathrm{~b}$ show the change of the enhancement factor for the UA16.15 and UA63.15 reactors filled with turbulence promoters in comparison with an empty flow channel using the data of Figures $8 \mathrm{a}$ and 9a. It can be seen that the enhancement factor in the presence of turbulence promoters in these "small" reactors decrease as the $R e$ number increases. This behavior is opposite to what has been observed in other electrochemical filter-press cells reported in the literature. ${ }^{31,34-38}$ Several reasons for these results are proposed below.

Figure 7. Mass transport characteristics of various filterpress reactors showing entry-length effects during the reduction of $4 \times 10^{-3} \mathrm{~mol} \mathrm{dm}^{-3}$ $\mathrm{Cu}$ (II) in $0.5 \mathrm{~mol} \mathrm{dm}^{-3}$ sodium sulfate at $\mathrm{pH} 2$.

(a) Log-log plot of Sherwood vs. Reynolds numbers for the UA16.15 reactor with various electrode areas exposed to the electrolyte; electrode areas: $(+) 3.1 \mathrm{~cm}^{2},(\times) 7.0 \mathrm{~cm}^{2}$, (*) 8 $\mathrm{cm}^{2}$, (口) $9.0 \mathrm{~cm}^{2}$, (○) $10.9 \mathrm{~cm}^{2}$, and (I) $16.0 \mathrm{~cm}^{2}$. (b) Log-log plot of mass transport coefficient vs. mean linear flow velocity for electrodes in the FM01-LC reactor with different lengths of entry and exit zones; $(\diamond) 0 \mathrm{~cm}$ and $(\Delta) 2.5 \mathrm{~cm} .{ }^{10}$ (c) $\mathrm{Log}-\mathrm{log}$ plot of mass transport coefficient vs. mean linear flow velocity for the UA63.03 reactor ${ }^{25}$ with different entry length and exit length zones; ( $0 \mathrm{~cm}$ and $(\diamond) 3 \mathrm{~cm}$.

Month 2008 Vol. 00, No. 0

AIChE Journal 


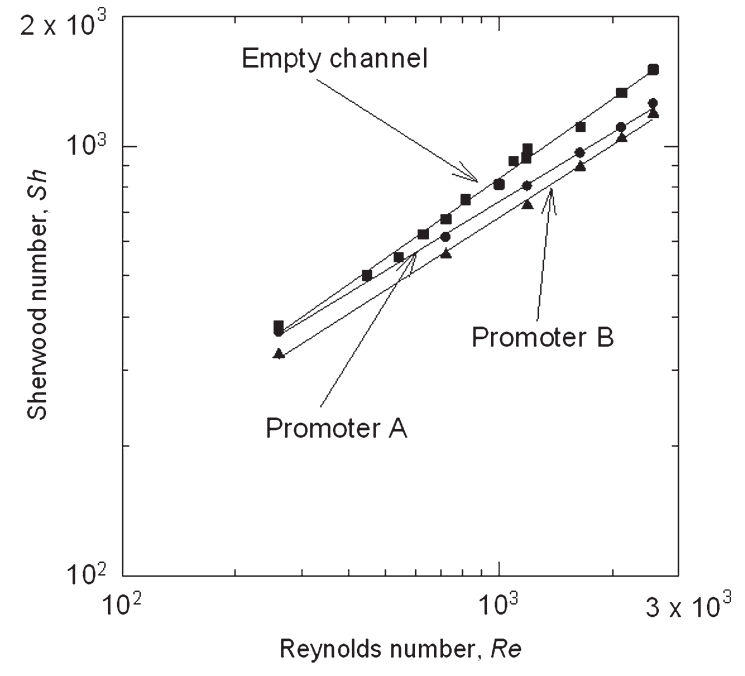

(a)

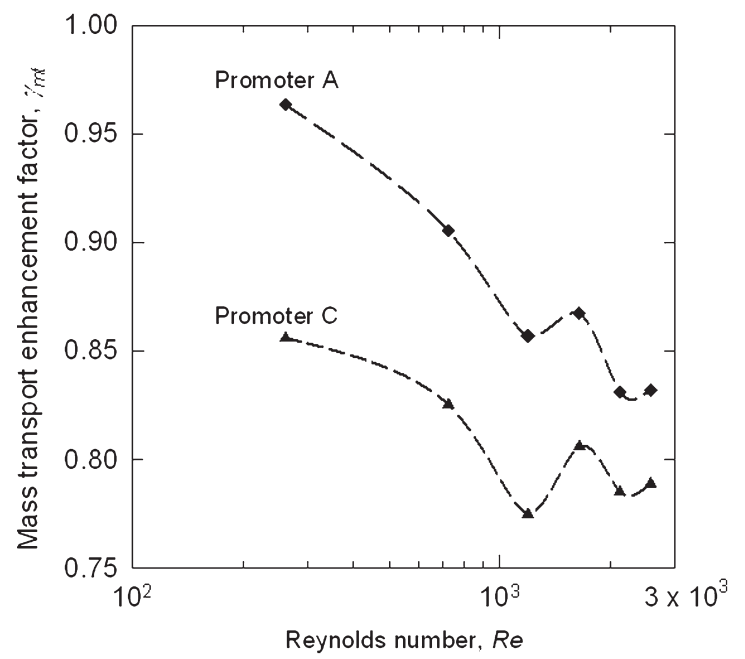

(b)

Figure 8. Mass transport characteristics of the UA16.15 reactor.

(a) Log-log plot of Sherwood number vs. Reynolds number for the UA16.15 reactor (with and without turbulence promoters) for the cathodic reduction of $\mathrm{Cu}(\mathrm{II})$ ion in 0.5 mol $\mathrm{dm}^{-3}$ sodium sulfate at $\mathrm{pH} 2$ : (口) Empty channel, (O) turbulence promoter A, and ( $\mathbf{\Delta})$ turbulence promoter C. (b) Mass transport enhancement factor (relative to an empty channel, $\gamma=1$ ) vs. Reynolds number for the presence of promoters $\mathrm{A}(\boldsymbol{\bullet})$ and $\mathrm{C}(\boldsymbol{\Delta})$.

Turbulence promoters fitted in industrial scale filter-press reactors usually enhances global mass transport rates, but the results of this study carried out in relatively small filter-press cells showed consistently lower mass transport rates. Three possible effects that can cause reduction of the global mass transport when turbulence promoters were used can be as follows: (a) the turbulence promoter seats on the active surface area of the electrode blocking the access for the electroactive species and decreasing the current, (b) the turbulence promoters diverts the fluid flow forming preferential channels forming a bypass of the fluid, and (c) the structure formed by the turbulence promoter leads to localized flow recirculation and creation of stagnant zones, which diminish the mass transport rate. The recirculation zones are produced by sudden change in the flow direction at the manifolds entrance, when the electrolyte from the inlet jets expands into the reactor compartment and dominates the flow distribution. To evaluate these factors, the projected area of the open spaces of the turbulence promoters and the surface blocked by the promoter strands (or filaments) in contact with the electrode were measured and are reported in Table 3 .

The open space of the turbulence promoters varies between 47 and $58 \%$ of the area, while the area of the elec-

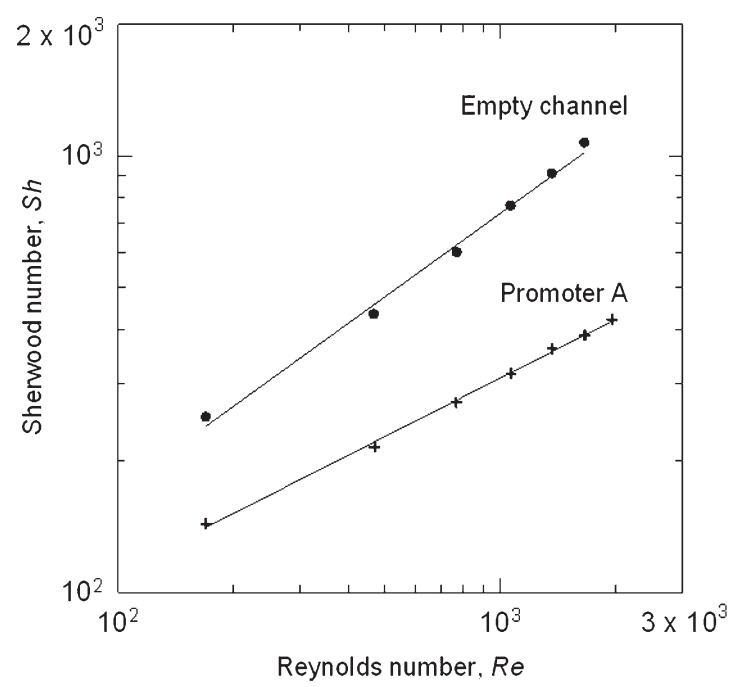

(a)

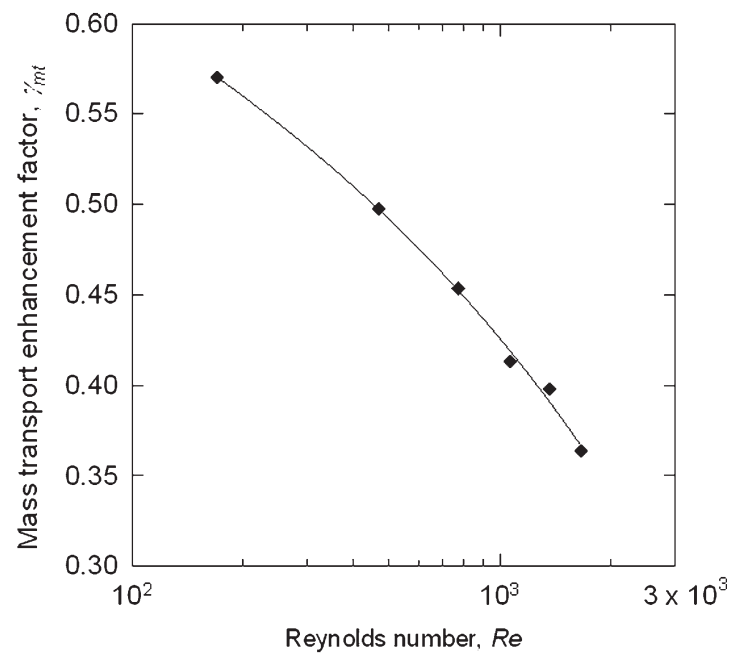

(b)

Figure 9. Mass transport characteristics of the UA 63.15 reactor.

(a) Log-log plot of Sherwood number vs. Reynolds number during the cathodic reduction of $\mathrm{Cu}(\mathrm{II})$ ions within the concentration range of $1-4 \mathrm{~mol} \mathrm{dm}^{-3}$ in $0.5 \mathrm{~mol} \mathrm{dm}^{-3}$ sodium sulfate at $\mathrm{pH}$ 2: $(-)$ empty compartment and $(+)$ compartment containing turbulence promoter A. (b) Mass transport enhancement factor (relative to an empty channel, $\gamma=1$ ) vs. Reynolds number in the presence of turbulence promoter A. 
trode blocked by the strands of the turbulence promoters is in the range of $28-46 \%$. These two factors do not seem to be the cause of the observed decrease in the mass transport coefficients of less than 25\%. As can be seen in Figure 8b, the decrease in the enhancement factor depends on the different geometrical features of the turbulence promoters; for example, promoter A has higher overall 2D surface blockage than promoter $\mathrm{C}$, however, the decay in the mass transport enhancement factor for promoter A was lower than for promoter $\mathrm{C}$. The fact that the enhancement factor depends on the Reynolds number indicates that the reason of the decay in the mass transport enhancement factor is not due to the blockage of the surface (fixed conditions not dependent to the convective conditions), and other possible reasons such as the channeling effects mentioned earlier should be investigated. Further flow dispersion and residence time distribution experiments are necessary to investigate the turbulence promoter effect in these cells.

Using a computational fluid dynamics (CFD) analysis, Karode and Kumar ${ }^{39}$ studied the effect of through filled turbulence promoter channels on the fluid flow structure. The study highlighted the fact that the bulk of the electrolyte flows parallel to the spacer filaments and depends on the geometric properties of the spacers (symmetric or asymmetric filaments of the nets).

\section{Dimensionless parameters for the characterization of manifold design: entrance length effects}

Several attempts to characterize the effect of entrance/exit manifolds on the mass transport behavior in electrochemical reactors can be found in the literature. Pickett and Wilson ${ }^{8}$ suggested that the fully developed flow regime in a parallelplate reactor occurred after a distance $L^{*}$, of approximately $6 \cdot d_{e}$ from the reactor inlet. This relationship has been used to obtain the values reported in Table 4 . The parameter $L^{*}$ provides a simple mean to express the influence of the entrance/exit effect, however, the relationship does not include the distribution, number and type of ports, and their effect on the resultant electrolyte flow conditions, which can decrease the minimum length $L^{*}$. Djati et al. ${ }^{21}$ proposed a relationship between the cross-sectional areas of the fluid inlet of the electrochemical reactor geometry in an attempt to characterize the manifold design. Figure 10 shows the $S h$ vs. Re dimensionless relationship for the UA and the FM01-LC ${ }^{40}$ reactors, and demonstrates that the influence of the entrance/ exit effect strongly depends on the manifold geometry. Large differences exist in the Sherwood number between the UA16.15 and UA63.15 reactors, which contain small bore holes in the entrance and exit manifold, in comparison with the UA63.03 and the FM01-LC reactors, which contain larger slots in the inlet/outlet manifolds.

To quantify the effect of the entrance/exit manifold, we propose a geometrical manifold parameter $\psi$. This parameter is more developed than the parameter suggested by Djati et al., ${ }^{21}$ and takes into account aspects of the manifold design such as thickness, width, geometrical distribution of the open spaces, and the free area for the electrolyte entrance within reactor. The characteristic geometric parameters of the flow distributors found in the reactors presented in this work, and those of the UA63.03 and FM01-LC reactors taken from the

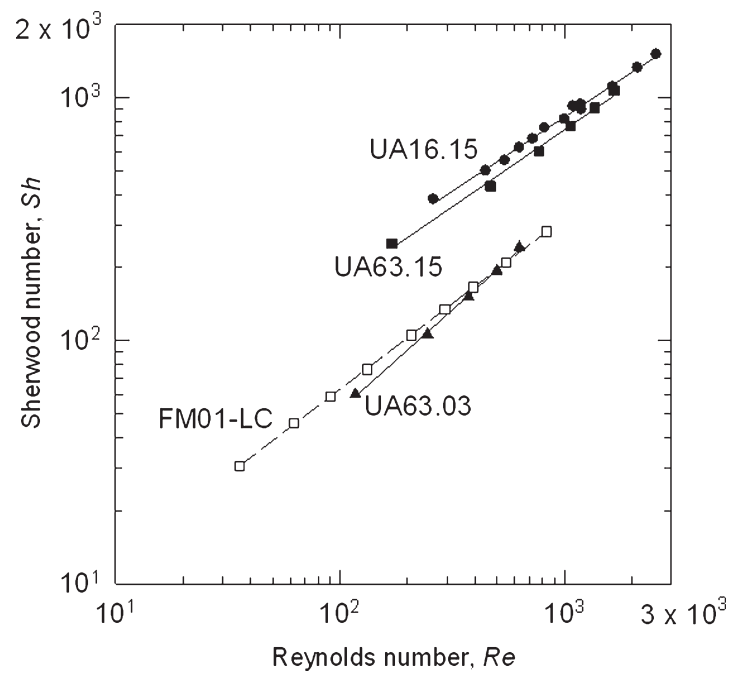

Figure 10. Log-log plot of Sherwood number vs. Reynolds number for the (O) UA16.15, (D) UA63.15, (A) UA63.03, and ( $\square$ ) FM01-LC reactors in the absence of turbulence promoters.

For the UA reactors, the data was obtained from the cathodic reduction of $\mathrm{Cu}(\mathrm{II})$ ion within a concentration range of $1-4 \mathrm{~mol} \mathrm{dm}^{-3}$ in $0.5 \mathrm{~mol} \mathrm{dm}{ }^{-3}$ sodium sulfate at $\mathrm{pH}$ 2. The results from the FM01-LC cell were obtained with $5 \times 10^{-3}$ mol dm ${ }^{-3}$ of $\mathrm{Cu}$ (II) in $1.5 \mathrm{~mol} \mathrm{dm}^{-3} \mathrm{Na}_{2} \mathrm{SO}_{4}$ at a flat nickel plate. ${ }^{40}$

literature are shown in Table 6. The geometrical manifold parameter, $\psi$, is given by,

$$
\psi=\frac{\gamma}{L \lambda \zeta / d_{e}}
$$

where $L$ is the length of the compartment, $\zeta$ is the free area for liquid entrance within the reactor (expressed as the ratio of whole area of the electrode channel to the manifold cross sectional area); $\lambda$ considers the geometrical arrangement of the holes in the flow distributor and $\gamma$ is the aspect ratio. The parameters $\lambda, \zeta$, and $\gamma$ are defined by,

$$
\begin{gathered}
\lambda=\frac{n_{\mathrm{h}} \cdot n_{\mathrm{r}}}{\gamma} \\
\zeta=\frac{n_{\mathrm{h}} n_{\mathrm{r}} \cdot A_{\text {hole }}}{B \cdot S} \\
\gamma=\frac{S}{B}
\end{gathered}
$$

where $n_{\mathrm{h}}$ is the number of holes in one row and $n_{\mathrm{r}}$ is the number of rows in the distribution manifold. The parameter $\zeta$ is equivalent to that suggested by Djati et al., ${ }^{21} A_{\text {hole }}$ is the cross-sectional area of an individual hole; in the case of a circular hole, $A=\pi d^{2} / 4$. High values of $\zeta$ are usually associated with low $S h$ numbers, while values close to 1 indicate ideal parallel-plate reactor behavior. A reactor with no holes in the distribution manifold cannot generate jet streams at the channel inlet and will exhibit low entrance/exit effects. Low values of $\zeta$ indicate behavior close to a jet inlet with a high turbulent zone near the reactor entrance. In a free channel, 
Table 6. Geometrical parameters describing inlet/outlet parameters for UA and FM01-LC filter-press reactors, $n=n_{r} \cdot n_{h}$

\begin{tabular}{|c|c|c|c|c|c|c|c|c|c|c|}
\hline Reactor & $\begin{array}{c}d_{e}=2 B S / \\
(B+S)(\mathrm{cm})\end{array}$ & $L e=L / d_{e}$ & $\gamma=S / B$ & $L / L^{*}=L / 6 d_{e}$ & $\begin{array}{c}B S \\
\left(\mathrm{~cm}^{2}\right)\end{array}$ & $\begin{array}{c}n \cdot \pi \\
d^{2} / 4\left(\mathrm{~cm}^{2}\right)\end{array}$ & $\zeta \times 10^{2}$ & $\lambda$ & $\psi \times 10^{2}$ & Reference \\
\hline UA16.15 & 2.2 & 1.82 & 0.36 & 0.31 & 6.0 & 0.44 & 7.3 & 37.3 & 7.6 & Present work \\
\hline UA63.15 & 2.5 & 3.70 & 0.21 & 0.61 & 10.5 & 0.82 & 7.8 & 124 & 0.6 & Present work \\
\hline UA63.03 & 0.6 & 15.5 & 0.043 & 2.6 & 2.1 & 0.72 & 34.3 & 46.6 & 0.02 & Present work \\
\hline FM01-LC & 1.0 & 16.5 & 0.14 & 2.7 & 2.2 & 0.23 & 10.5 & 29.0 & 0.27 & Present work \\
\hline Wragg et al. duct $1: 1$ & 5.2 & 19.2 & 1 & 3.2 & 27.3 & 27.3 & 100 & 1 & 5.2 & 7,13 \\
\hline $1: 2$ & 5.2 & 19.2 & 1 & 3.2 & 27.3 & 6.8 & 25 & 1 & 20.9 & 7,13 \\
\hline $1: 3$ & 5.2 & 19.2 & 1 & 3.2 & 27.3 & 3.0 & 11 & 1 & 47.4 & 7,13 \\
\hline $1: 6$ & 5.2 & 19.2 & 1 & 3.2 & 27.3 & 0.76 & 3 & 1 & 186 & 7,13 \\
\hline Pickett and Wilson & 1.6 & 24.8 & 0.19 & 4.13 & 4.75 & 0.13 & 2.7 & 5.3 & 5.5 & 8 \\
\hline Goodridge et al. & 2.3 & 6.58 & 0.32 & 0.38 & 7.12 & 0.59 & 8.3 & 9.5 & 6.1 & 15 \\
\hline Oduoza and Wragg & 2.3 & 6.58 & 0.32 & 0.38 & 7.12 & 2.30 & 32.3 & 3.2 & 4.7 & 19 \\
\hline Slit type $(\mathrm{ST}) *$ & 3.5 & 14.2 & 0.13 & 2.36 & 30 & 3.00 & 10 & 7.5 & 1.2 & 21 \\
\hline Tube type (TT1)* & 3.5 & 14.2 & 0.13 & 2.36 & 30 & 0.28 & 0.9 & 7.5 & 13.0 & 21 \\
\hline Tube type (TT2)* & 3.5 & 14.2 & 0.13 & 2.36 & 30 & 1.13 & 3.8 & 7.5 & 3.2 & 21 \\
\hline Tube type (TT3)* & 3.5 & 14.2 & 0.13 & 2.36 & 30 & 1.78 & 5.8 & 7.5 & 2.1 & 21 \\
\hline
\end{tabular}

*Nomenclature used in $^{21}$ referring to the characteristic geometries of different fluid inlets.

the aspect ratio $\gamma$ takes into account the possibility of high degree of channeling inside the compartment because of the narrow free space between the two parallel plates. Values of $\gamma$ close to 1 are expected at high $S h$ numbers indicating low degree of channeling and possible recirculation zones. Low values of the aspect ratio relationship means totally developed fluid flow conditions and channeling.

In this study, a simplified manifold design was assumed; only the case of homogeneous arrangement with symmetrical rows of holes in the distribution manifolds has been considered.

Table 7 shows the geometric manifold parameter $\psi$ and the area ratio $\zeta$ corresponding to each reactor at different values of the product $S h \cdot S c^{-1 / 3}$ at two Reynolds numbers. Some values of $S h \cdot S c^{-1 / 3}$ have been extrapolated from the mass transport correlations found in literature. The data show that the geometrical manifold parameter $\psi$ depends on the entrance/exit manifold design. It is thought that for multiple port manifolds, some discrepancies arise and the value of the parameter is very low. Large values of $\psi$ are associated with high values of $S h$ number and related to high entrance/exit

Table 7. Change of the Geometric Manifold Parameters, $\Psi$ and $\zeta$, for Various Reactor Designs Showing the Values of $S h \cdot S c^{1 / 3}$ and Reynolds numbers

\begin{tabular}{|c|c|c|c|c|}
\hline \multirow[b]{3}{*}{ Reactor (reference) } & \multicolumn{4}{|c|}{ Dimensionless Parameters } \\
\hline & \multirow[b]{2}{*}{$\Psi \times 10^{2}$} & \multirow[b]{2}{*}{$\zeta \times 10^{2}$} & \multicolumn{2}{|c|}{$S h \cdot S c^{-1 / 3}$} \\
\hline & & & $\begin{array}{c}R e= \\
250\end{array}$ & $\begin{array}{l}R e= \\
1,250\end{array}$ \\
\hline UA63:03 $3^{25}$ & 0.1 & 34.4 & 15.8 & 59.2 \\
\hline FM01-LC ${ }^{10,26}$ & 0.3 & 10.5 & 11.1 & 34.9 \\
\hline UA $63: 15$ (this work) & 0.6 & 7.8 & 27.3 & 75.5 \\
\hline Slit type $(\mathrm{ST})^{21 *}$ & 1.2 & 10.0 & 11.5 & 33.2 \\
\hline Tube type $(\mathrm{TT} 3)^{21_{*}}$ & 2.1 & 5.9 & 14.7 & 47.5 \\
\hline Tube type $(\mathrm{TT} 2)^{21 *}$ & 3.2 & 3.8 & 17.5 & 56.5 \\
\hline Goodridge et al. $^{15}$ & 6.1 & NA & 8.3 & 61.5 \\
\hline UA16:15 (this work) & 7.6 & 7.4 & 31.4 & 83.8 \\
\hline Tube type $(\mathrm{TT} 1)^{21 *}$ & 13.0 & 1.0 & 36.6 & 119.0 \\
\hline
\end{tabular}

NA, not available.

*Nomenclature used $i^{21}$ referring to the characteristic geometries of different fluid inlets. effects regimes. Meanwhile, low values of the geometrical manifold parameter $\psi$ are related to manifold designs that allow faster reattachment points, where different fluid streams become into a unique developed fluid flow pattern, and to manifolds that allow total developed flow regime.

The geometrical manifold parameter, $\psi$ provides a valuable statement of the importance of jet flow effects at the inlet due to manifold design. It is a useful tool, combined with $d_{e}$, to estimate and quantify the entrance effects in parallel-plate reactors including filter-press cells.

\section{Conclusions}

(1) Three main parameters have been used to characterize manifold and reactor geometry; (a) the geometric manifold parameter $\psi$ that summarizes the influence of manifold design, (b) the parameter $\lambda$ which gives the relative position of the ports in the entrance/exit manifolds, and (c) the parameter $\zeta$, previously presented in the literature, shows the influence on the mass transport conditions of the inlet/exit zones focused on the fluid inlet/outlet area vs. total geometrical area. This parameter does not take into account the distribution of the fluid inlet area inside the total geometric area.

(2) The introduction of turbulence promoters in a largescale, filter-press reactor can increase the global mass transport rate significantly. The insertion of such promoters in small reactors, however, can cause the opposite effect since the entrance/exit manifold effects dominate in these cells and the electrolyte flow is not fully developed.

(3) Despite the above considerations, the use of sufficiently small cells (such as the UA16.15 reactor) where the total electrode area is affected by the entrance/exit effects provide recirculation areas at any of the experimental flow rates used.

(4) The decrease in the mass transport coefficient $k_{\mathrm{m}}$ caused by the turbulence promoters is mainly because of the flow channeling. The blocked area alone does not justify the observed decrease of the enhancement factor. The effect of the turbulent promoters strongly depends on the specific geometrical features of the fibers (or filaments), which constitute the net in the turbulent promoters; their geometrical shape and size are important. 


\section{Notation}

$A_{\text {hole }}=$ electrode area, $\mathrm{m}^{2}$

$a=$ coefficient in the mass transport correlation, Eq. 2, dimensionless

$B=$ breadth of the flow channel (perpendicular to the direction of flow), $\mathrm{m}$

$b=$ Reynolds number exponent in the mass transport correlation, Eq. 2, dimensionless

$c=$ Schmidt number exponent in the mass transport correlation, Eq. 2, dimensionless

$c_{\mathrm{b}}=$ Bulk concentration of reactant, $\mathrm{mol} \mathrm{m} \mathrm{m}^{-3}$

$d=$ manifold hole diameter, $\mathrm{m}$

$d_{e}=$ Equivalent (hydraulic) diameter of the flow channel, $(=2 B S /$ $(B+S)), \mathrm{m}$

$D=$ diffusion coefficient of reactant, $\mathrm{m}^{2} \mathrm{~s}^{-1}$

$F=$ Faraday constant, 96,485 $\mathrm{C} \mathrm{mol}^{-1}, \mathrm{C} \mathrm{mol}^{-1}$

$I_{\mathrm{L}}=$ limiting current, A

$j_{\mathrm{L}}=$ limiting current density, $\mathrm{A} \mathrm{m}^{-2}$

$k_{\mathrm{m}}=$ mass transport coefficient, $\mathrm{m} \mathrm{s}^{-1}$

$L=$ length of the reactor compartment in the direction of flow, $\mathrm{m}$

$L^{*}=$ fully developed flow regime length, $\mathrm{m}$

$n_{\mathrm{h}}=$ number of hole distributors, dimensionless

$n_{\mathrm{r}}=$ number of rows of hole distributors in the manifold, dimensionless

$\Delta P=$ pressure drop, $\mathrm{Pa}$

$S=$ thickness of flow channel, $\mathrm{m}$

$v=$ mean linear flow velocity, $\mathrm{m} \mathrm{s}^{-1}$

$V_{\mathrm{r}}=$ channel volume $(=B L S \varepsilon), \mathrm{m}^{3}$

$z=$ number of electrons in the electrode process, dimensionless

\section{Dimensionless groups}

$f=$ friction factor, $\left(=\Delta P d_{e} / 2 \rho L v^{2}\right)$, dimensionless

$R e=$ Reynolds number $\left(=v d_{e} / v\right)$, dimensionless

$S c=$ Schmidt number $(=v / D)$, dimensionless

$S h=$ Sherwood number $\left(=k_{m} d_{e} / D\right)$, dimensionless

\section{Greek letters}

$\varepsilon=$ volumetric porosity of turbulence promoter, dimensionless $\gamma=$ aspect ratio of the flow channel, $(=S / B)$, Eq. 10, dimensionless $\gamma_{\mathrm{mt}}=$ Mass transport enhancement factor, Eq. $(6 \mathrm{a}, \mathrm{b})$, dimensionless

$\psi=$ geometrical manifold parameter, Eq. 7, dimensionless

$\lambda=$ geometrical arrangement parameter, Eq. 8, dimensionless

$\zeta=$ area ratio manifold design parameter, Eq. 9, dimensionless

$v=$ kinematic viscosity of electrolyte, $\mathrm{m}^{2} \mathrm{~s}^{-1}$

$\rho=$ fluid density of electrolyte $\mathrm{kg} \mathrm{m}^{-3}$

\section{Literature Cited}

1. Walsh FC. A First Course in Electrochemical Engineering, 1st ed. Romsey, UK: The Electrochemical Consultancy, 1993.

2. Goodridge F, Scott K. Electrochemical Process Engineering, 1st ed. London: Plenum Press, 1995.

3. Cooper JA, Compton R. Channel electrodes-a review. Electroanalysis. 1998; 10:141-155.

4. Walsh FC, Robinson D. Electrochemical synthesis and processing in modern filter-press reactors. Chem Technol Eur. 1994;May/June:16-23.

5. Pletcher D, Walsh FC. Industrial Electrochemistry, 2nd ed. London: Blackies, 1993.

6. González-García J, Sánchez-Cano G, Montiel V, Aldaz A. Procedimiento de fabricación de electrodos de dióxido de plomo. Spanish Pat. 9,401,259 (1994).

7. Tagg DJ, Patrick MA, Wragg AA. Heat and mass transfer downstream of abrupt nozzle expansions in turbulent flow. Trans I Chem E. 1979;57:176-181.

8. Pickett DJ, Wilson CJ. Mass transfer in a parallel plate electrochemical cell-the effect of change of flow cross-section at the cell inlet. Electrochim Acta. 1982;27:591-594.

9. Barral G, Maximovitch S, Montella C. Study of a laboratory filterpress cell by impedance spectroscopy. J Appl Electrochem. 1991; 21:991-997.

10. Brown CJ, Pletcher D, Walsh FC, Hammond JK, Robinson D. Studies of space-averaged mass transport in the FM01-LC laboratory electrolyser. J Appl Electrochem. 1993;23:38-43.
11. Ralph TR, Hitchman ML, Millington JP, Walsh FC. Mass transport in an electrochemical laboratory filter-press reactor and its enhancement by turbulence promoters. Electrochim Acta. 1996;41: 591-603.

12. Brown CJ, Pletcher D, Walsh FC, Hammond JK, Robinson D. Local mass transport effects in the FM01-LC laboratory electrolyser. J Appl Electrochem. 1992;22:613-619.

13. Wragg AA, Tagg DJ, Patrick MA. Diffusion-controlled current distributions near cell entries and corners. $J$ Appl Electrochem. 1980;10:43-47.

14. Chouikhi SM, Patrick MA, Wragg AA. Mass transfer downstream of nozzles in turbulent pipe flow with varying Schmidt number. $J$ Appl Electrochem. 1987; 17:1118-1128.

15. Goodridge F, Mamoor GM, Plimley RE. Mass transfer rates in baffled electrolytic cells. I Chem E Symp Ser. 1986;98:61-71.

16. Wragg AA, Leontaritis AA. Mass transfer measurements in a parallel pate cell using the limiting current technique. In: Kreysa G, editor. Electrochemical Cell Design and Optimisation. Dechema Monograph, Vol. 123. Weinheim, VCH, 1992:345-360.

17. Wragg AA, Leontaritis AA. Local mass transfer and current distribution in baffled and unbaffled parallel plate electrochemical reactors. Chem Eng J. 1997;66:1-10.

18. Oduoza CF, Wragg AA. Effects of baffle length on mass transfer in a parallel plate rectangular electrochemical cell. J Appl Electrochem. 2000;30:1439-1444.

19. Oduoza CF, Wragg AA. Local mass-transfer distribution in the channels of a serpentine flow baffled parallel plate cell. Chem Eng J. 2002;85:119-126.

20. Szánto DA, Trinidad P, Whyte I, Walsh FC. Electrosynthesis and mass transport measurements in laboratory filter-press reactors, in "Proceedings of 4th European Symposium on Electrochemical Engineering: Contemporary Trends in Electrochemical Engineering," Prague, Czech Republic, August 28-30, 1996:273.

21. Djati A, Brahimi M, Legrand J, Saidani B. Entrance effect on mass transfer in a parallel plate electrochemical reactor. J Appl Electrochem. 2001;31:833-837.

22. Wang Y, Postlethwaite J, Bergstrom DJ. Modelling mass transfer entrance lengths in turbulent pipe-flow with applications to small cathodes for measuring local mass transfer rates. J Appl Electrochem. 1996;26:471-479.

23. Bogard DG, Thole KA. Wall-bounded turbulent flows. In: Johnson RW, editor. The Handbook of Fluid Dynamics. Heidelberg, Germany: Springer-Verlag, 1998.

24. Janna WS. Internal incompressible viscous flow. In: Johnson RW, editor. The Handbook of Fluid Dynamics. Heidelberg, Germany: Springer-Verlag, 1998.

25. González-García J, Conesa JA, Iniesta J, García-García V, Montiel V, Aldaz A. Characterization of an electrochemical laboratory filterpress reactor by hydrodynamic and mass transport studies. I Chem E Symp Ser. 1999;145:51-60.

26. Griffiths M, Ponce de León C, Walsh FC. Mass transport in the rectangular channel of a filter-press electrolyzer (the FM01-LC Reactor). AIChE J. 2005;51:682-687.

27. Hine F, Yasuda M, Ogata Y, Hara K. Hydrodynamic studies on a vertical electrolyzer with gas evolution under forced circulation. J Electrochem Soc. 1984;131:83-89.

28. Brown CJ, Walsh FC, Pletcher D. Mass transfer and pressure drop in a laboratory filter-press electrolyser. Trans I Chem E. 1996;73A: 196-205.

29. Levich VG. Physicochemical Hydrodynamics. New Jersey: PrenticeHall, 1962:32.

30. Coeuret F, Storck A. Eléments de Génie Électrochimique Technique et Documentation. Paris: Lavoisier 1984:95.

31. González-García J, Frías A, Expósito E, Montiel V, Aldaz A, Conesa JA. Characterization of an electrochemical pilot-plant filterpress reactor by hydrodynamic and mass transport studies. Ind Eng Chem Res. 2000;39:1132-1142.

32. Letord-Quéméré MM, Coeuret F, Legrand J. Mass transfer at the wall of a thin channel containing an expanded turbulence promoting structure. J Electrochem Soc. 1998;135:3063-3067.

33. Walsh FC, Reade GW. Design and performance of electrochemical reactors of efficient synthesis and environmental treatment. Part 1. Electrode Geometry Figures Merit Analyst. 1994;119:791196. 
34. Winograd Y, Solan A, Toren M. Mass transfer in narrow channels in the presence of turbulence promoters. Desalination. 1973;13:171186.

35. Storck A, Coeuret F. Mass and momemtum transfer at a wall in the presence of turbulence promoters. Electrochim Acta. 1997;22:11551160 .

36. Letord-Quéméré MM, Legrand J, Coeuret F. Improvement of mass transfer in electrochemical cells by means of expanded materials. I Chem E Symp Ser. 1986;98:73-83.

37. Brown CJ, Pletcher D, Walsh FC, Hammond JK, Robinson D. Studies of 3-dimensional electrodes in the fm01-lc laboratory electrolyzer. J Appl Electrochem. 1994;24:95-106.
38. Walsh FC, Reade GW. Design and performance of electrochemical reactors of efficient synthesis and environmental treatment. Part 2. Typical Reactors Performance Analyst. 1994;119:797-803.

39. Karode SK, Kumar A. Flow visualization through spacer filled channels by computational fluid dynamics I. Pressure drop and shear rate calculations for flat sheet geometry. J Membrane Sci. 2001;193:6984.

40. Szánto D, Trinidad P, Walsh FC. Evaluation of carbon electrodes and electrosynthesis of coumestan and catecholamine derivatives in the FM01-LC electrolyser. J Appl Electrochem. 1998;28:251-258.

Manuscript received July 24, 2007, and revision received Nov. 27, 2007. 
AQ1: Kindly check whether the affiliations are OK as typeset.

AQ2: Please check whether the sentence "Important factors include ... heat transfer similarities." is OK as edited.

AQ3: Kindly check whether the sentence "The effect of the turbulent ... and size are important." is OK as edited.

AQ4: Kindly check whether the Tables are OK as typeset. 